\title{
Metals uptake behaviour in Miscanthus $x$ giganteus plant during growth at the contaminated soil from the military site in Sliač, Slovakia
}

\author{
Valentina V. Pidlisnyuk ${ }^{1 *}$, Larry E. Erickson ${ }^{2}$, Josef Trögl ${ }^{1}$, Pavlo Y. Shapoval ${ }^{3}$, Jan Popelka ${ }^{4}$, \\ Lawrence C. Davis ${ }^{5}$, Tetyana R. Stefanovska ${ }^{6}$, Ganga M. Hettiarachchi ${ }^{7}$ \\ ${ }^{1} J a n$ Evangelista Purkyně University in Ústí nad Labem, Department of Technical Sciences, Králova Výšina 3132/7, Ústí \\ nad Labem, Czech Republic \\ ${ }^{2}$ Kansas State University, Department of Chemical Engineering, 1005 Durland Hall, Manhattan, Kansas, USA \\ ${ }^{3}$ National University "Lvivska Polytechnika”, Department of Analytical Chemistry, Sv.Yura Square 9, Lviv, Ukraine \\ ${ }^{4} J a n$ Evangelista Purkyně University in Ústí nad Labem, Department of Informatization and Geoinformatization, Králova \\ Výšina 3132/7, Ústí nad Labem, Czech Republic \\ ${ }^{5}$ Kansas State University, Department of Biochemistry and Molecular Biophysics, 141 Charmers Hall, Manhattan, Kansas, \\ USA \\ ${ }^{6}$ National University of Life and the Environmental Sciences, Department of Plant Protection, Gerojiv Oboronu 13, Kyiv, \\ Ukraine \\ ${ }^{7}$ Kansas State University, Department of Agronomy, Throckmorton Hall, 1712 Claflin Road, Manhattan, Kansas, USA \\ "Corresponding author: e-mail: pidlisnyuk@gmail.com
}

\begin{abstract}
Peculiarities of metals uptake by the biofuel crop Miscanthus $x$ giganteus were explored during plant growth at soil from the military site (Sliač, Slovakia). The experiment was carried out in greenhouse during two vegetation seasons. Research soil was predominantly elevated in $\mathrm{Fe}$ and $\mathrm{Ti}$, while other metals (As, $\mathrm{Cu}, \mathrm{Mn}, \mathrm{Sr}, \mathrm{Zn}$ and $\mathrm{Zr}$ ) were presented at order of magnitude lower concentrations. No inhibition of plant growth was observed. The calculated Bioconcentration Factor showed that levels of metals' accumulation by plant roots, stems and leaves were independent of metals' concentrations in the soil. The accumulation of metals by stems and leaves was much lower than by roots. As, Zr, Ti were almost not accumulated by stems and leaves during both seasons; accumulation of $\mathrm{Cu}, \mathrm{Fe}, \mathrm{Mn}, \mathrm{Zn}$ and $\mathrm{Sr}$ was not essential which confirmed that biomass of M. $x$ giganteus might be processed for the energy purpose.
\end{abstract}

Keywords: Miscanthus $x$ giganteus, military site, non-parametric statistics, metals uptake behavior.

\section{INTRODUCTION}

Phytoremediation is a proven technique for recovery of contaminated soils ${ }^{1-4}$. The approach was born from the observation that plants possess physiological properties useful for environmental remediation. This was shortly followed by application of breeding techniques and artificial selection to genetically improve some of the more promising and interesting species ${ }^{5}$. Phytoremediation is inexpensive and ecologically friendly, effective for large areas with moderate concentrations of contaminants and it has a good potential for cleaning brown-fields and contaminated sites ${ }^{6}$. A growing number of research projects are examining the union of two processes, i.e. phytoremediation with synchronized production of biofuel crops $^{7-8}$. The main reason is the possibility of restoring marginal land to agricultural food crop use $\mathrm{e}^{9}$ and fulfilling the growing demand for biomass as an alternative energy source $^{\mathbf{1 0}}$. Second generation biofuel crops are becoming favored because they are not in competition with main agricultural food crop production ${ }^{11-13}$.

Second generation biofuel crops include short rotation trees and annual or perennial grasses. The sterile, perennial grass Miscanthus $x$ giganteus is considered as one of the most promising for uniting of phytoremediation or phytostabilization and production of biofuels ${ }^{14-17}$. M. $x$ giganteus (Giant Chinese Silver Grass), is a large, perennial grass interspecifichybrid of Miscanthus sinensis and Miscanthus sacchariflorus ${ }^{18}$ which occurs naturally in temperate to sub-tropical areas of Asia, but it has been successfully grown also in the cool temperate climate of Europe and the US ${ }^{19}$. This plant is a peren- nial grass with woody stems reaching of heights of 2 to $4 \mathrm{~m}$. The above-ground vegetation senesces in autumn, but the plant regrows vigorously in the spring from its rhizomatous root system. Plants can be harvested in winter at a high dry matter content, giving the biomass favorable combustion properties ${ }^{20}$. Other potential uses for miscanthus include geotextiles, building applications or paper pulp ${ }^{21}$.

Miscanthus has a C-4 photosynthetic pathway, and has been demonstrated to achieve high conversion efficiency for C-4 plants, which exceed those of C-3 crop plants traditionally grown in Northern Europe ${ }^{11}$. M. $x$ giganteus was introduced in Europe and exhibited good production properties while used for remediation of brownfield sites, former mining sites and contaminated agricultural lands ${ }^{9,14,17}$. One of the main interest of miscanthus for the perennial management of contaminated sites is the restoration of soil diversity and functionality ${ }^{22-25}$.

Clifton-Brown et $\mathrm{al}^{26}$ have recently provided a thorough analysis of the potential for seed-based propagation of miscanthus hybrids. They fully outline the benefits of miscanthus as a bio-fuel crop for use on marginal lands particularly in Europe, while advocating for a more economical reproduction and planting scheme based on hybrid seed rather than rhizomes. With proper choice of hybrids, this may allow agriculturalists to broaden the geographic range for economically viable use of miscanthus as a biofuel, and for phytoremediation. Until the time that such seed-based reproduction systems become generally available, there is still great value to documenting suitable strategies for establishing $M . x$ giganteus, the commonly available biofuel miscanthus, on contaminated 
lands. We initiated investigations on the possibility of using M. $x$ giganteus for restoration of former military sites located in Slovakia, Ukraine, Czech Republic, USA and Croatia ${ }^{27-29}$.

That study is presented results of the investigation done at the soil taken from the former military site located near village Sliač, Slovakia and control soil taken near village Velká Luka. The military site was used as an airport of the former Soviet Union Air Force, and was classified as highly contaminated by the Slovakian Environmental Agency and Ministry of Defense of the Slovak Republic. Spilled jet fuel (kerosene) was the main contaminant ${ }^{30}$. In addition, the area has relatively high arsenic levels due to its complex geology as the downstream region of a highly erosive river system descending from mountainous central Slovakia ${ }^{31}$. Epidemiological studies have indicated increased levels of basal cell carcionoma attributable to elevated As in water sources in the Banska Bystrica district which includes the town of Sliač ${ }^{32}$. This source site, along the Hron River, is a luvisol derived from erosion upstream in the mineral-rich mountains that are derived from volcanic action. The immediate area is relatively level, as befits a major airport.

The aim of this study was to test in a greenhouse pot experiment the uptaken of the metals from the contaminated military soil while growing the crop $M$. x giganteus at that soil during two growing seasons, 2014 and 2015, to calculate a Bioconcentration Factor (BCF), to analyse peculiarities of the process and to compare the metals uptake behavior in the plant during first and second vegetation seasons.

\section{EXPERIMENTAL}

\section{Soil}

The location of the studied contaminated military site had the following coordinate: Latitude: $48^{\circ} 62^{\prime} 34$; Longitude: $19^{\circ} 13^{\prime} 49$. The site was chosen as research one in accordance with the assessment of Sliač-South done by the Ministry of Defense of the Slovak Republic in 2013. The assessment detected ${ }^{33}$ five contaminated sites, i.e.: military storages with the contaminated surface 664 $\mathrm{m}^{2}$ and $109 \mathrm{~m}^{2}$; car parking place at the water bridge with the contaminated surface $281 \mathrm{~m}^{2}$; car parking place near the office building with the contaminated surface $178 \mathrm{~m}^{2}$; garage yard with the contaminated surface 173 $\mathrm{m}^{2}$. The soil for the research was taken from the biggest contaminated area: former military storage. The soil from that location was collected on April, 28th, 2014. The sampling of the control (relatively "clean") soil was withdrawn from the agricultural field at the nearby located village Velká Luka on the opposite bank of the Hron river which had the following coordinate: Latitude: $48^{0} 63^{\prime} 02$; Longitude: $19^{0} 15^{\prime} 57$. The soil from control site was taken on April, 29th, 2014. The soil sampling at contaminated site at Sliač and control site at Velká Luka was carried out using the standard envelope approach ${ }^{34}$.

The agricultural characteristics of the contaminated soil from Sliač were measured in accordance with the standards ${ }^{35-37}$.

\section{Pot experiment}

The pot experiment was carried out in the greenhouse. Fourteen kg of soil in each pot in duplicates (labeled $\mathrm{a}$ and $\mathrm{b}$ ) was used. Concentration series of five mixtures of control and contaminated soils was used: $100 \%, 75 \%$, $50 \%, 25 \%$ and $0 \%$ of contaminated soil numbered 1 a to $5 \mathrm{a}$ and $1 \mathrm{~b}$ to $5 \mathrm{~b}$, respectively. In each pot two rhizomes of M. x giganteus were planted. Rhizomes were three years old obtained from the agricultural station in Bytča, Žilina region, Slovakia.

Pots were watered as necessary by tap water during growing seasons. The first year experiment started on $29^{\text {th }}$ April 2014 and ended on $12^{\text {th }}$ December 2014 when stems and leaves had withered and were cut down. Pieces of rhizomes were sampled from each pot for analysis. For the winter season pots with rhizomes were stored in dark dry conditions until $1^{\text {st }}$ April 2015. The second year of the experiment started on $2^{\text {nd }}$ April 2015 when the first sprouts appeared; that day pots were taken back to the light in the greenhouse. Year two growth ended on $21^{\text {st }}$ October 2015 when stems and leaves withered. They were cut and together with rhizomes were withdrawn from pots for analysis. The overall accumulation of metals into the roots, stems and leaves of $M$. x giganteus was determined at the end of the two growing seasons of 2014 and 2015. The height of the plants (in $\mathrm{cm}$ ) were measured during vegetation seasons occasionally using ruler.

\section{Analyses}

Preparation of soil samples for analysis was carried as following. The soil sample was dried at $105^{\circ} \mathrm{C}$ to constant mass. The dry sample was put on the clean sheet of paper and small stones, plant particles and other inclusions were removed. Bigger soil clods were rubbed in a porcelain mortar and mixed with the main part of the soil sample. The average soil sample for analysis was prepared by the following approach: the carefully mixed soil sample was put on the clean paper in a form of a square and divided in four equal parts by spatula. Two opposite parts were rejected, and two others were combined, mixed and divided again and taken further for the analysis. The final average sample was additionally sifted through the sieve with a diameter of holes 0.25 $\mathrm{mm}$, the bigger particles were milled if necessary.

Preparation of samples from roots, stems and leaves for analysis was done as following. The samples of roots were carefully cleaned with distilled water and dried in open air. The samples of roots, stems and leaves were dried at $105^{\circ} \mathrm{C}$ to constant mass, cooled in desiccators 1 hour and weighed. Dried samples were burned at $450^{\circ} \mathrm{C}$ for 4 hours, cooled in desiccators 1 hour and weighed.

The determination of concentrations of metals in the soil, roots, stems and leaves was provided by X-Ray fluorescence analysis using analyzer Expert-3L. The device was produced at the Institute for Analytical Methods of Control, Kyiv, Ukraine (http://inam.kiev.us/ contact-information) in accordance with the requirements of EPA $6200^{38}$. The device had the following technical characteristic: spectrometer used Si-pin detector with resolution of $155 \mathrm{eV}$ for $\mathrm{K} \alpha \mathrm{Mn}$; X-ray emitter had superior stability with voltage range at the anode of the X-ray tube from 10 to $50 \mathrm{kV}$ (stability is $0.01 \%$ ) and current range at the anode from 5 to $200 \mathrm{mkA}$ 
(stability is $0.05 \%$ ). Enhanced design of analyzer housing provided full dust and moisture protection, allowed operation in the temperature range from $+10^{\circ} \mathrm{C}$ to $+45^{\circ} \mathrm{C}$, relative humidity $<90 \%$ and ensured complete user radiation protection. The accuracy of determination has been constantly controlled by State Enterprice "Ukrmetrteststandart", Kyiv, Ukraine in accordance with ISO/IEC $17025^{39}$.

This energy dispersion X-ray technique uses low-power $\mathrm{X}$-ray tube and detection by semiconductor PIN-detector equipped with thermo-electric cooling. Determination of elements from $11 \mathrm{Na}$ to $92 \mathrm{U}$ was simultaneously in a single measurement. The range of the measured element contents $-0.005-100 \%$. Detection limits of elements from $1-10 \mathrm{ppm}$.

The device can detect chemical elements in a range $11 \mathrm{Na}$ till $92 \mathrm{U}$ with high accuracy $(0.01 \%)$. The time of data collection was $2 \times 300 \mathrm{~s}$ for all samples. Limits of absolute measuring error were $\pm 0.05-0.2 \%$ (with the time of one measurement $300 \mathrm{~s}$ ). Three parallel measurements were taken for each sample. The level of metals in the soil was determined in $\mathrm{mg} / \mathrm{kg}$. For the roots, stems and leaves, levels were determined in mass units in the ash and then further recalculated to $\mathrm{mg} / \mathrm{kg}$ based on ash content of plant material. For overall calculation the concentration was expressed in $\mathrm{mg} / \mathrm{kg}$ dry weight. In case of soil analysis, sample $(\sim 2 \mathrm{~g})$ were placed on ultra-thin $(4 \mu \mathrm{m})$ polypropylene film (supplied with the device), which is transparent to X-rays, further accurately transferred to the device where measurement was performed. In case of plant parts, combusted samples (ash) of roots, stems and leaves were placed inside a glass ring with diameter of $1.25 \mathrm{~cm}$, which was located on a similar thin polypropylene film and compacted using a glass rod. The resulting sample was transferred into a device for measurements. The quantities of plant samples were enough to do three parallel measures.

\section{Statistics}

Statistical evaluation of data received was carried out using Microsoft Excel. Since a majority of data did not pass the Jarque-Bera normality test (Table 1), non-parametric statistics (Spearman correlation, Friedman test,) were applied ${ }^{40}$. The non-parametric calculations were carried out using PAST 3.0 software (Natural History Museum, University of $\mathrm{Oslo}^{41}$ ) at the significance level $\alpha=0.05$.

\section{RESULTS AND DISCUSSION}

The agricultural characteristic of the soil is presented at Table 2, and content of metals in soil samples is presented in Table 3. The soils contained dominantly Fe and $\mathrm{Ti}$, and other metals $(\mathrm{Mn}, \mathrm{Cu}, \mathrm{Zn}, \mathrm{Zr}$ ) are present at order of magnitude lower concentrations. With the exception of As, the soils contained all other elements within the range of elemental concentrations reported for uncontaminated soils collected from around the world ${ }^{42}$. The upper limit of As concentration reported for uncontaminated soils is $40 \mathrm{mg} / \mathrm{kg}^{\mathbf{4 3}}$. Both soils had elevated As concentrations $(290 \mathrm{mg} / \mathrm{kg}$ in the control and $425 \mathrm{mg} / \mathrm{kg}$ in the contaminated soil) confirming that these soils from Slovakia are also contaminated with that element as reported before ${ }^{27-28}$.

The measuring of the M. x giganteus height during two years of experiment is presented at Table 4. In accordance with that data plants growth well at all types of

Table 2. Characteristics of used soil

\begin{tabular}{|c|c|}
\hline Parameter & Value \\
\hline $\mathrm{pH}^{*}$ & 7.06 \\
\hline $\mathrm{C}_{\mathrm{ox}}[\mathrm{g} / \mathrm{kg}]^{* *}$ & 14.60 \\
\hline Humus $[\mathrm{g} / \mathrm{kg}]^{* *}$ & 25.16 \\
\hline Ntot $[\mathrm{g} / \mathrm{kg}]^{*}$ & 2.97 \\
\hline extractable $^{\star \star *} \mathrm{P}[\mathrm{mg} / \mathrm{g}]$ & 13.59 \\
\hline extractable ${ }^{* * *} \mathrm{~K}[\mathrm{mg} / \mathrm{kg}]$ & 156.96 \\
\hline extractable $^{* \star *} \mathrm{Mg}[\mathrm{mg} / \mathrm{kg}]$ & 630.80 \\
\hline
\end{tabular}

the mixed contaminated soils and there was not obvious inhibition of growth neither differences in plant's height in between first and second vegetation seasons.

The concentrations of metals in the roots, stems and leaves (detected at the end of growing seasons of 2014 and 2015) were used for calculation of the BCF in accordance with ${ }^{4}$ :

$\mathrm{BCF}=$ Concentration of metal in roots, stems or leaves $(\mathrm{mg} / \mathrm{kg}) /$ concentration of metals in the soil $(\mathrm{mg} / \mathrm{g})$.

The calculated values of BCF are presented at Table 5 . Generally, the values of BCF for all researched metals are significantly lower for stems and leaves than for roots. All values of $\mathrm{BCF}$ are also significantly lower than 1 , which indicates absence of metals' hyperaccumulation by $M . x$ giganteus plant. This is in accordance to the published data for similar research systems ${ }^{17,28}$.

Despite significant gradient of metal concentrations in the soils (variants 1 to 5), no correlation is observed between level of soil pollution and metals concentration

Table 1. Normality Jarque-Bera test of metal concentrations in the plant parts.

\begin{tabular}{|c|c|c|c|c|c|c|}
\hline & \multicolumn{2}{|c|}{ Roots } & \multicolumn{2}{|c|}{ Stems } & \multicolumn{2}{|c|}{ Leaves } \\
\hline & year 1 & year 2 & year 1 & year 2 & year 1 & year 2 \\
\hline $\mathrm{Ti}$ & 0.52 & 0.57 & 10.70 & 0.74 & 3.57 & 1.05 \\
\hline $\mathrm{Mn}$ & 6.04 & 0.99 & 7.79 & 0.91 & 0.99 & 1.03 \\
\hline $\mathrm{Cu}$ & 0.94 & 3.54 & 1.22 & 0.27 & 0.31 & 4.09 \\
\hline $\mathrm{Zn}$ & 0.37 & 0.45 & 1.03 & 1.05 & 2.03 & 0.75 \\
\hline As & 3.18 & 0.82 & 5.37 & 22.74 & 1.17 & 8.07 \\
\hline $\mathrm{Zr}$ & 0.94 & 0.64 & 5.23 & 22.74 & 2.03 & 13.57 \\
\hline
\end{tabular}


Table 3. Concentrations of metals in mixtures of contaminated and control soils (average \pm standard deviation, $\mathrm{n}=2$ ) taken from contaminated site at Sliac and control site at Velka Luka, the Slovak Republic.

\begin{tabular}{|l|c|c|c|c|c|}
\hline soil label & 1 & 2 & 3 & 4 & 5 \\
\hline control soil & $100 \%$ & $75 \%$ & $50 \%$ & $25 \%$ & 0 \\
\hline contaminated s. & $0 \%$ & $25 \%$ & $50 \%$ & $75 \%$ & $100 \%$ \\
\hline As $[\mathrm{mg} / \mathrm{kg}]$ & 290 & 515 & 430 & 465 & 425 \\
\hline $\mathrm{Cu}[\mathrm{mg} / \mathrm{kg}]$ & 310 & 380 & 395 & 440 & 565 \\
\hline $\mathrm{Fe}[\mathrm{mg} / \mathrm{kg}]$ & 174555 & 194485 & 205640 & 209480 & 215210 \\
\hline $\mathrm{Mn}[\mathrm{mg} / \mathrm{kg}]$ & 2995 & 3605 & 9110 & 4495 & 4660 \\
\hline $\mathrm{Sr}[\mathrm{mg} / \mathrm{kg}]$ & 685 & 24410 & 25935 & 27940 & 1200 \\
\hline $\mathrm{Ti}[\mathrm{mg} / \mathrm{kg}]$ & 20620 & 1025 & 1115 & 1205 & 28170 \\
\hline $\mathrm{Zn}[\mathrm{mg} / \mathrm{kg}]$ & 960 & 1455 & 1345 & 1500 & 1015 \\
\hline $\mathrm{Zr}[\mathrm{mg} / \mathrm{kg}]$ & 1275 & & & & 1625 \\
\end{tabular}

Table 4. Height of Mxgiganteus $(\mathrm{cm})$ during growing at mixed soils taken from contaminated site at Sliac and control site at Velka Luka, the Slovak Republic in 2014-2015 years

\begin{tabular}{|c|c|c|c|c|c|}
\hline soil label $-\mathrm{A}$ & 1 & 2 & 3 & 4 & 5 \\
\hline control soil & $100 \%$ & $75 \%$ & $50 \%$ & $25 \%$ & $0 \%$ \\
\hline contaminated s. & $0 \%$ & $25 \%$ & $50 \%$ & $75 \%$ & $100 \%$ \\
\hline \multicolumn{6}{|c|}{2014} \\
\hline 15.05 & $26.50 \pm 0.04$ & $19.50 \pm 0.02$ & $26.90 \pm 0.02$ & $19.20 \pm 0.03$ & $23.30 \pm 0.02$ \\
\hline 09.06 & $98.00 \pm 0.04$ & $87.60 \pm 0.05$ & $94.90 \pm 0.02$ & $90.60 \pm 0.02$ & $97.40 \pm 0.03$ \\
\hline 05.07 & $196.50 \pm 0.05$ & $179.20 \pm 0.04$ & $187.40 \pm 0.05$ & $165.50 \pm 0.03$ & $181.80 \pm 0.05$ \\
\hline 07.11 & $218.00 \pm 0.05$ & $212.10 \pm 0.05$ & $215.90 \pm 0.05$ & $189.20 \pm 0.05$ & $222.90 \pm 0.02$ \\
\hline \multicolumn{6}{|c|}{2015} \\
\hline 26.05 & $39.50 \pm 0.02$ & $38.70 \pm 0.02$ & $35.20 \pm 0.01$ & $28.40 \pm 0.01$ & $40.50 \pm 0.01$ \\
\hline 25.06 & $132.30 \pm 0.05$ & $129.80 \pm 0.03$ & $101.50 \pm 0.05$ & $107.50 \pm 0.05$ & $109.20 \pm 0.05$ \\
\hline 02.09 & $202.20 \pm 0.04$ & $187.50 \pm 0.05$ & $209.80 \pm 0.03$ & $175.80 \pm 0.05$ & $211.50 \pm 0.06$ \\
\hline 21.10 & $215.00 \pm 0.04$ & $200.60 \pm 0.04$ & $219.50 \pm 0.05$ & $190.50 \pm 0.03$ & $212.00 \pm 0.05$ \\
\hline soil label $-\mathrm{B}^{*}$ & 1 & 2 & 3 & 4 & 5 \\
\hline \multicolumn{6}{|c|}{2014} \\
\hline 15.05 & $20.90 \pm 0.02$ & $24.00 \pm 0.02$ & $19.90 \pm 0.01$ & $24.70 \pm 0.02$ & $19.30 \pm 0.01$ \\
\hline 9.06 & $95.50 \pm 0.02$ & $101.00 \pm 0.03$ & $90.80 \pm 0.03$ & $100.10 \pm 0.03$ & $90.80 \pm 0.02$ \\
\hline 05.07 & $179.20 \pm 0.02$ & $182.20 \pm 0.04$ & $185.10 \pm 0.04$ & $181.00 \pm 0.03$ & $185.00 \pm 0.05$ \\
\hline 07.11 & $197.00 \pm 0.05$ & $203.00 \pm 0.04$ & $211.90 \pm 0.05$ & $205.90 \pm 0.04$ & $207.00 \pm 0.04$ \\
\hline \multicolumn{6}{|c|}{2015} \\
\hline 26.05 & $33.50 \pm 0.02$ & $40.60 \pm 0.03$ & $30.00 \pm 0.01$ & $32.00 \pm 0.01$ & $33.90 \pm 0.01$ \\
\hline 25.06 & $129.00 \pm 0.02$ & $139.80 \pm 0.03$ & $111.00 \pm 0.05$ & $98.80 \pm 0.05$ & $120.80 \pm 0.05$ \\
\hline 02.09 & $197.50 \pm 0.04$ & $191.20 \pm 0.05$ & $195.90 \pm 0.04$ & $179.30 \pm 0.04$ & $207.00 \pm 0.06$ \\
\hline 21.10 & $200.10 \pm 0.05$ & $195.60 \pm 0.04$ & $202.50 \pm 0.05$ & $201.00 \pm 0.04$ & $218.00 \pm 0.04$ \\
\hline
\end{tabular}

* - the same mixing as for soil label A

in plant parts (Table 5) as well as plants height (Table 4). That fact is detected for both growing seasons and illustrates that metals are uptake by $M$. x giganteus with no regard to contamination of researched military soil. Such plant behavior was previously observed for $M$. $x$ giganteus growth at another military contaminated soil taken from Kamenetz-Podilsky, Ukraine ${ }^{28}$.

The Spearman correlation of metal concentrations in soil and different plant parts to dilution series is presented at Table 6 . The majority of metals concentrations in the soil correlate significantly with percentage of contaminants (Table 6, line 1) thus confirming contamination of the site by metals and existence of concentration gradients in the soils.

This result enabled comparison of metals concentrations in plant parts jointly for all variants in order to obtain higher significance of comparisons based on higher number of values. Non-parametric Friedman test with post-hoc Wilcoxon test of metals concentrations are presented in Table 7.

The analysis of data presented at Table 7 show that, in accordance with expectation, the uptake of metals by $M . x$ giganteus roots is the biggest in comparison with the above parts of the plant and the phenomena observed for all monitored metals. Also, the level of accumulation of metals in the roots is higher at the end of the second growing season for all metals which is in accordance with the previously reported results, when $M x$ giganteus was used at the different phytoremediation processes $^{4,9,14-15}$. The data presented at Table 6 and Table 7 illustrate the essential differences in metal's accumulation level by plant's roots: when $\mathrm{As}, \mathrm{Cu}, \mathrm{Sr}$, $\mathrm{Zn}, \mathrm{Zr}$ are accumulated relatively not essential, $\mathrm{Fe}, \mathrm{Mn}$, $\mathrm{Ti}$ are accumulated significantly.

Analysis of data presented at Table 6 show that BCF of metals by above part of the plants is different. With that regards the behavior of all monitored metals can be divided into four relative groups. The biggest value of $\mathrm{BCF}$ is observed for $\mathrm{Cu}$, both-for stems and leaves in the first vegetation season, and the value decreases in the second year of growth. Mn shows insignificant BCF for above plant's tissues which is relatively stable during both vegetation seasons. $\mathrm{Sr}$ and $\mathrm{Zn}$ show an insignificant BCFs to above plant's tissues at the first year of growth which decrease at the second year of vegetation, that is similar to behavior of $\mathrm{Cu}$. The forth group is formed by As, $\mathrm{Fe}, \mathrm{Ti}$ and $\mathrm{Zr}$ : for that metals BCFs are equal to zero in both vegetation seasons.

The data presented at Table 7 illustrate the differences in metals' uptake between first and second growing seasons. The results show that metals' up taken by above part of the plant is very limited during both seasons 
Table 5. BCF (concentration in plant part / concentration in soil, average \pm std. deviation, $\mathrm{n}=2$ )

\begin{tabular}{|c|c|c|c|c|c|}
\hline soil label & 1 & 2 & 3 & 4 & 5 \\
\hline control soil & $100 \%$ & $75 \%$ & $50 \%$ & $25 \%$ & $0 \%$ \\
\hline \begin{tabular}{|l|} 
contaminated soil \\
\end{tabular} & $0 \%$ & $25 \%$ & $50 \%$ & $75 \%$ & $100 \%$ \\
\hline \multicolumn{6}{|l|}{$\mathrm{c}$ [mg/kg dwt] } \\
\hline As roots year 1 & $\leq 0.01$ & $0.02 \pm 0.01$ & $\leq 0.01$ & $\leq 0.01$ & $0.03 \pm 0.02$ \\
\hline As stems year 1 & $\leq 0.01$ & $\leq 0.01$ & $\leq 0.01$ & $\leq 0.01$ & $\leq 0.01$ \\
\hline As leaves year 1 & $\leq 0.01$ & $\leq 0.01$ & $\leq 0.01$ & $\leq 0.01$ & $\leq 0.01$ \\
\hline As roots year 2 & $0.08 \pm 0.03$ & $0.08 \pm 0.01$ & $0.05 \pm 0.01$ & $0.05 \pm 0.01$ & $0.04 \pm 0.02$ \\
\hline As stems year 2 & $\leq 0.01$ & $\leq 0.01$ & $\leq 0.01$ & $\leq 0.01$ & $\leq 0.01$ \\
\hline As leaves year 2 & $\leq 0.01$ & $\leq 0.01$ & $\leq 0.01$ & $\leq 0.01$ & $\leq 0.01$ \\
\hline Cu roots year 1 & $0.13 \pm 0.03$ & $0.24 \pm 0.05$ & $0.12 \pm 0.03$ & $0.09 \pm 0.04$ & $0.15 \pm 0.02$ \\
\hline Cu stems year 1 & $0.07 \pm 0.01$ & $0.04 \pm 0.01$ & $0.08 \pm 0.02$ & $0.05 \pm 0.03$ & $0.06 \pm 0.04$ \\
\hline Cu leaves year 1 & $0.08 \pm 0.01$ & $0.07 \pm 0.01$ & $0.06 \pm 0.01$ & $0.06 \pm 0.02$ & $0.06 \pm 0.02$ \\
\hline Cu roots year 2 & $0.24 \pm 0.14$ & $0.19 \pm 0.04$ & $0.3 \pm 0.18$ & $0.15 \pm 0.06$ & $0.10 \pm 0.05$ \\
\hline Cu stems year 2 & $0.02 \pm 0.01$ & $0.03 \pm 0.01$ & $\leq 0.01$ & $0.02 \pm 0.01$ & $\leq 0.01$ \\
\hline Cu leaves year 2 & $0.02 \pm 0.01$ & $0.03 \pm 0.01$ & $0.03 \pm 0.01$ & $0.02 \pm 0.01$ & $\leq 0.01$ \\
\hline Fe roots year 1 & $\leq 0.01$ & $\leq 0.01$ & $\leq 0.01$ & $\leq 0.01$ & $\leq 0.01$ \\
\hline Fe stems year 1 & $\leq 0.01$ & $\leq 0.01$ & $\leq 0.01$ & $\leq 0.01$ & $\leq 0.01$ \\
\hline Fe leaves year 1 & $\leq 0.01$ & $\leq 0.01$ & $\leq 0.01$ & $\leq 0.01$ & $\leq 0.01$ \\
\hline Fe roots year 2 & $0.1 \pm 0.04$ & $0.14 \pm 0.08$ & $0.14 \pm 0.02$ & $0.12 \pm 0.01$ & $0.08 \pm 0.03$ \\
\hline Fe stems year 2 & $\leq 0.01$ & $\leq 0.01$ & $\leq 0.01$ & $\leq 0.01$ & $\leq 0.01$ \\
\hline Fe leaves year 2 & $\leq 0.01$ & $\leq 0.01$ & $\leq 0.01$ & $\leq 0.01$ & $\leq 0.01$ \\
\hline Mn roots year 1 & $0.03 \pm 0.01$ & $0.05 \pm 0.02$ & $\leq 0.01$ & $0.02 \pm 0.01$ & $\leq 0.01$ \\
\hline Mn stems year 1 & $\leq 0.01$ & $\leq 0.01$ & $\leq 0.01$ & $\leq 0.01$ & $\leq 0.01$ \\
\hline Mn leaves year 1 & $0.05 \pm 0.01$ & $0.07 \pm 0.01$ & $0.03 \pm 0.01$ & $0.05 \pm 0.01$ & $0.05 \pm 0.01$ \\
\hline Mn roots year 2 & $0.12 \pm 0.06$ & $0.17 \pm 0.09$ & $0.12 \pm 0.02$ & $0.13 \pm 0.03$ & $0.08 \pm 0.03$ \\
\hline Mn stems year 2 & $0.06 \pm 0.01$ & $0.05 \pm 0.01$ & $0.02 \pm 0.01$ & $0.02 \pm 0.01$ & $0.02 \pm 0.01$ \\
\hline Mn leaves year 2 & $0.06 \pm 0.01$ & $0.05 \pm 0.01$ & $0.03 \pm 0.01$ & $0.02 \pm 0.01$ & $0.03 \pm 0.01$ \\
\hline Sr roots year 1 & $0.06 \pm 0.04$ & $0.07 \pm 0.02$ & $0.02 \pm 0.01$ & $0.02 \pm 0$ & $0.04 \pm 0.02$ \\
\hline Sr stems year 1 & $0.07 \pm 0.04$ & $0.06 \pm 0.01$ & $0.04 \pm 0.01$ & $0.02 \pm 0.01$ & $0.04 \pm 0.02$ \\
\hline Sr leaves year 1 & $0.08 \pm 0.01$ & $0.07 \pm 0.04$ & $0.05 \pm 0.01$ & $0.05 \pm 0.03$ & $0.04 \pm 0.01$ \\
\hline Sr roots year 2 & $0.15 \pm 0.10$ & $0.22 \pm 0.14$ & $0.22 \pm 0.09$ & $0.1 \pm 0.01$ & $0.08 \pm 0.01$ \\
\hline Sr stems year 2 & $0.02 \pm 0.01$ & $0.02 \pm 0.01$ & $\leq 0.01$ & $\leq 0.01$ & $\leq 0.01$ \\
\hline Sr leaves year 2 & $0.05 \pm 0.02$ & $0.03 \pm 0.01$ & $0.02 \pm 0.01$ & $0.02 \pm 0.01$ & $0.02 \pm 0.01$ \\
\hline Ti roots year 1 & $\leq 0.01$ & $\leq 0.01$ & $\leq 0.01$ & $\leq 0.01$ & $\leq 0.01$ \\
\hline Ti stems year 1 & $\leq 0.01$ & $\leq 0.01$ & $\leq 0.01$ & $\leq 0.01$ & $\leq 0.01$ \\
\hline Ti leaves year 1 & $\leq 0.01$ & $\leq 0.01$ & $\leq 0.01$ & $\leq 0.01$ & $\leq 0.01$ \\
\hline Ti roots year 2 & $0.11 \pm 0.05$ & $0.13 \pm 0.07$ & $0.15 \pm 0.03$ & $0.12 \pm 0.01$ & $0.10 \pm 0.03$ \\
\hline Ti stems year 2 & $\leq 0.01$ & $\leq 0.01$ & $\leq 0.01$ & $\leq 0.01$ & $\leq 0.01$ \\
\hline Ti leaves year 2 & $\leq 0.01$ & $\leq 0.01$ & $\leq 0.01$ & $\leq 0.01$ & $\leq 0.01$ \\
\hline Zn roots year 1 & $0.06 \pm 0.01$ & $0.05 \pm 0.02$ & $0.05 \pm 0$ & $0.07 \pm 0.03$ & $0.09 \pm 0.04$ \\
\hline Zn stems year 1 & $0.08 \pm 0.01$ & $0.10 \pm 0.02$ & $0.13 \pm 0.01$ & $0.10 \pm 0.03$ & $0.16 \pm 0.09$ \\
\hline Zn leaves year 1 & $0.04 \pm 0.01$ & $0.04 \pm 0.01$ & $0.04 \pm 0.01$ & $0.03 \pm 0.01$ & $0.05 \pm 0.01$ \\
\hline Zn roots year 2 & $0.11 \pm 0.04$ & $0.17 \pm 0.06$ & $0.22 \pm 0.08$ & $0.2 \pm 0.02$ & $0.15 \pm 0.07$ \\
\hline Zn stems year 2 & $0.06 \pm 0.02$ & $0.07 \pm 0.02$ & $0.05 \pm 0.03$ & $0.10 \pm 0.01$ & $0.08 \pm 0.01$ \\
\hline Zn leaves year 2 & $0.05 \pm 0.01$ & $0.07 \pm 0.02$ & $0.06 \pm 0.02$ & $0.05 \pm 0.01$ & $0.06 \pm 0.01$ \\
\hline Zr roots year 1 & $\leq 0.01$ & $\leq 0.01$ & $\leq 0.01$ & $\leq 0.01$ & $\leq 0.01$ \\
\hline Zr stems year 1 & $\leq 0.01$ & $\leq 0.01$ & $\leq 0.01$ & $\leq 0.01$ & $\leq 0.01$ \\
\hline Zr leaves year 1 & $\leq 0.01$ & $\leq 0.01$ & $\leq 0.01$ & $\leq 0.01$ & $\leq 0.01$ \\
\hline Zr roots year 2 & $0.04 \pm 0.01$ & $0.06 \pm 0.03$ & $0.14 \pm 0.04$ & $0.11 \pm 0.01$ & $0.08 \pm 0.02$ \\
\hline Zr stems year 2 & $\leq 0.01$ & $\leq 0.01$ & $\leq 0.01$ & $\leq 0.01$ & $\leq 0.01$ \\
\hline Zr leaves year 2 & $\leq 0.01$ & $\leq 0.01$ & $\leq 0.01$ & $\leq 0.01$ & $\leq 0.01$ \\
\hline
\end{tabular}

referring to the concentration of metals in the soils. Consequently, As and $\mathrm{Zr}$ are almost not accumulated by stems and leaves during both vegetation seasons and accumulation of $\mathrm{Cu}, \mathrm{Mn}, \mathrm{Zn}$ and $\mathrm{Sr}$ is not essential which confirmed that biomass may be processed for the energy. Moreover, data presented at Table 7 illustrate the interesting fact: for some metals accumulation by the above part of $M$. x giganteus decreases at the second year of vegetation in comparison with the first year: that effect is observed for $\mathrm{Cu}$ and $\mathrm{Sr}$ (stems and leaves); $\mathrm{Fe}$ (stems); Mn (leaves) and $\mathrm{Zn}$ (stems).

Previous studies ${ }^{15,17,28}$ showed that $M . x$ giganteus demonstrated good growth on the contaminated and marginal soils with limited accumulation of metals in the aboveground parts. Results obtained in current research complemented that data in terms of growing plants on the military contaminated soil with high concentrations of $\mathrm{Fe}, \mathrm{Ti}$, As and other metals with no obvious inhibition of growth and limited uptake of metals to the aboveground parts. In general, the pathway of metal(loid)s in soil to above ground plants parts is insignificant ${ }^{42-43}$. The current research is in agreement with this observation. Such behavior is favorable for application of M. $x$ giganteus as source of biomass for the direct burning, fermentation to biofuels. Further research is still needed regarding improving quality and quantity of $M$. x giganteus biomass growing at the abandoned military sites and economical aspects of the process. 
Table 6. Spearman correlation of metal concentrations in soil and different plant parts to dilution series. Red bold indicate significant correlations $(\mathrm{P}<0.05)$

\begin{tabular}{|l|c|c|r|r|r|r|r|r|}
\hline & $\mathrm{As}$ & $\mathrm{Cu}$ & $\mathrm{Fe}$ & $\mathrm{Mn}$ & $\mathrm{Sr}$ & $\mathrm{Ti}$ & $\mathrm{Zn}$ & $\mathrm{Zr}$ \\
\hline Soil & 0.19 & 0.78 & 0.81 & 0.79 & 0.89 & 0.91 & 0.11 & 0.40 \\
\hline Roots year 1 & 0.49 & 0.12 & 0.74 & -0.32 & 0.02 & 0.49 & 0.39 & 0.12 \\
\hline Stems year 1 & 0.07 & 0.05 & -0.10 & 0.35 & -0.07 & 0.07 & 0.54 & -0.16 \\
\hline Leaves year 1 & -0.24 & 0.37 & 0.54 & 0.39 & -0.10 & -0.24 & 0.02 & $\mathrm{NA}$ \\
\hline Roots year 2 & 0.32 & -0.20 & -0.02 & 0.02 & -0.07 & 0.32 & 0.22 & 0.49 \\
\hline Stems year 2 & -0.27 & -0.10 & 0.15 & -0.54 & -0.45 & -0.27 & 0.42 & 0.47 \\
\hline Leaves year 2 & -0.24 & -0.36 & -0.10 & -0.49 & 0.02 & -0.24 & 0.15 & 0.54 \\
\hline
\end{tabular}

NA - not available

Table 7. Concentrations of selected metals in M. $x$ giganteus parts in two vegetation seasons (average \pm standard deviation, $\mathrm{n}=10$ ). Letters denote comparable metal concentrations, based on Wilcoxon test $(\alpha=0.05)$

\begin{tabular}{|c|c|c|c|c|c|c|c|}
\hline & [mg/kg dwt] & \multicolumn{3}{|c|}{ Year 1} & \multicolumn{3}{|c|}{ Year 2} \\
\hline & soil & roots & stems & leaves & roots & stems & leaves \\
\hline As & $425 \pm 86 d$ & $6 \pm 6 b c$ & $1 \pm 1 \mathrm{ab}$ & $1 \pm 1 \mathrm{a}$ & $25 \pm 10 c$ & $\mathrm{NA} a$ & $\mathrm{NA} a$ \\
\hline $\mathrm{Cu}$ & $418 \pm 114 \mathrm{e}$ & $58 \pm 24 c d$ & $23 \pm 11 b c$ & $26 \pm 4 c$ & $76 \pm 48 d$ & $8 \pm 3 a b$ & $8 \pm 3 a$ \\
\hline $\mathrm{Fe}$ & $199874 \pm 15943 e$ & $1514 \pm 455 c$ & $119 \pm 34 a b$ & $213 \pm 33 b$ & $23779 \pm 10167 d$ & $101 \pm 36 a$ & $252 \pm 41 b$ \\
\hline $\mathrm{Mn}$ & $3973 \pm 748 d$ & $85 \pm 52 b$ & $20 \pm 20 a$ & $181 \pm 54 b c$ & $488 \pm 266 c$ & $131 \pm 55 b c$ & $131 \pm 43 b$ \\
\hline $\mathrm{Sr}$ & $938 \pm 230 c$ & $37 \pm 17 a b$ & $39 \pm 21 a b$ & $51 \pm 19 b$ & $135 \pm 78 b$ & $13 \pm 2 a$ & $24 \pm 10 a$ \\
\hline $\mathrm{Ti}$ & $25415 \pm 2994 d$ & $225 \pm 72 b$ & $8 \pm 19 a$ & $2 \pm 3 a$ & $3114 \pm 1180 c$ & $40 \pm 30 a$ & $33 \pm 24 a$ \\
\hline $\mathrm{Zn}$ & $1064 \pm 214 \mathrm{e}$ & $63 \pm 19 a c$ & $117 \pm 33 \mathrm{bd}$ & $40 \pm 4 a$ & $179 \pm 74 \mathrm{~cd}$ & $78 \pm 34 a b$ & $61 \pm 13 a$ \\
\hline $\mathrm{Zr}$ & $1140 \pm 224 d$ & $13 \pm 7 b$ & $1 \pm 1 \mathrm{a}$ & $\mathrm{NAa}$ & $125 \pm 61 c$ & NA a & $\mathrm{NAa}$ \\
\hline
\end{tabular}

NA - not available

\section{CONCLUSIONS}

The two-season-research confirmed the ability of $M$. $x$ giganteus to grow on the metal contaminated former military soil from Sliač, Slovakia without observed inhibition in growth. The Bioconcentration Factor is much lower for stems and leaves in comparison with roots. No correlation of metals in the plant parts to significant gradients in soils is found. That show that metals are taken up by plant parts with no regard to the soil contamination; however, uptake of individual metals by plant parts differed. The uptake of metals by $M . x$ giganteus roots is the biggest in comparison with the above part of the plant and the phenomena observes for all monitored metals. The level of metals' accumulation in the roots is higher for all metals at the end of the second growing season in comparison with the first one. The metals uptake by above part of $M x$ giganteus is rather small in comparison with the concentration of the metals in the soils: such metals as As, $\mathrm{Zr}, \mathrm{Fe}, \mathrm{Zr}$ are almost not accumulated by above part of the plant and level of accumulation of $\mathrm{Cu}, \mathrm{Mn}, \mathrm{Zn}$ and $\mathrm{Sr}$ is not essential, which confirmed that biomass may be processed further for the energy. The results confirmed applicability of $M$. $x$ giganteus for phytostabilization of military sites with further production of energy biomass.

\section{ACKNOWLEDGMENTS}

The research was supported by NATO SFP MYP G4687.

\section{LITERATURE CITED}

1. Karthikeyan, R., Davis, L.C., Erickson, L.E., Al-Khatib, K., Kulakow, P.A., Barnes, P.L., Hutchinson, S.L. \& Nurzhanova, A.A. (2004). Potential for plant-based remediation of pesticidecontaminated soil and water using nontarget plants such as trees, shrubs, and grasses. Critical Reviews in Plant Sciences. 23(1), 91-101. DOI: 10.1080/07352680490273518.
2. Davis, L.C., Erickson, L.E., Narayanan, M. \& Zhang, Q. (2003). Modeling and design of phytoremediation, In S.C.McCutcheon\&J. L.Schnoor (Eds), Phytoremediation: Transformation and Control of Contaminants (pp. 661-694). Science and Technology\&A Wiley-Intersciences Series of Texts and Monographs. DOI: 10.1002/047127304X.ch21.

3. Li, G.Y., Hu, N., Ding, D.X., Zheng, J.F., Liu, Y.L., Wang, Y.D. \& Nie, X.Q. (2011). Screening of plant species for phytoremediation of uranium, thorium, barium, nickel, strontium and lead contaminated soils from a uranium mill tailings repository in south china. Bulletin of Environmental Contamination and Toxicology. 86(6), 646-652. DOI: 10.1007/ s00128-011-0291-2.

4. Prasad, M.N.V. (2015). Bioremediation and bioeconomy (1st ed.). Elsevier Inc.

5. Maestri, E. \& Marmiroli N. (2011). Transgenic plants for phytoremediation. International Journal of Phytoremediation. 13(1), 264-279. DOI: 10.1080/15226514.2011.568549.

6. Witters, N., Mendelsohn, R.O., Van Slycken, S., Weyens, N., Schreurs, E., Meers, E., Tack, F., Carleer, R. \& Vangronsveld, J. (2012). Phytoremediation, a sustainable remediation technology? Conclusions from a case study. I: Energy production and carbon dioxide abatement. Biomass \& Bioenergy. 39, 454-469. DOI: 10.1016/j.biombioe.2011.08.016.

7. Witters, N., Van Slycken, S., Ruttens, A., Adriaensen, K., Meers, E., Meiresonne, L., Tack, F.M., Thewys, T., Laes, E. \& Vangronsveld, J. (2009). Short-rotation coppice of willow for phytoremediation of a metal-contaminated agricultural area: A sustainability assessment. BioEnergy Research. 2(3), 144-152. DOI: $10.1007 / \mathrm{s} 12155-009-9042-1$.

8. Gomes, H.I. (2012). Phytoremediation for bioenergy: Challenges and opportunities. Environmental Technology Reviews. 1(1), 59-66. DOI: 10.1080/09593330.2012.696715.

9. Nsanganwimana, F., Pourrut, B., Waterlot, C., Louvel, B., Bidar, G., Labidi, S., Fontaine, J., Muchembled, J., Sahraoui, A.L.H., Fourrier, H. \& Donay, F. (2015). Metal accumulation and shoot yield of miscanthus $\mathrm{x}$ giganteus growing in contaminated agricultural soils: Insights into agronomic practices. Agriculture Ecosystems \& Environment. 213, 61-71. DOI: 10.1016/j.agee.2015.07.023.

10. Brosse, N., Dufour, A., Meng, X.Z., Sun, Q.N. \& Ragauskas, A. (2012). Miscanthus: A fast-growing crop for biofuels 
and chemicals production. Biofuels Bioproducts \& BiorefiningBiofpr. 6(5), 580-598. DOI: 10.1002/bbb.1353.

11. Beale, C.V., Bint, D.A. \& Long, S.P. (1996). Leaf photosynthesis in the $\mathrm{c}$-4-grass miscanthus $\mathrm{x}$ giganteus, growing in the cool temperate climate of southern england. J. Exp. Bot. 47(2), 267-273. DOI: 10.1093/jxb/47.2.267.

12. Christian, D., Bullard, M. \& Wilkins, C. (1997). The agronomy of some herbaceous crops grown for energy in southern england. Aspects Appl. Biol. 49, 41-51.

13. Gopalakrishnan, G., Negri, M.C. \& Snyder, S.W. (2011). A novel framework to classify marginal land for sustainable biomass feedstock production. J. Environ. Qual. 40(5), 1593-1600. DOI: $10.2134 /$ jeq2010.0539.

14. Nsanganwimana, F., Pourrut, B., Mench, M. \& Douay, F. (2014). Suitability of miscanthus species for managing inorganic and organic contaminated land and restoring ecosystem services. A review. J. Environ. Manage. 143, 123-134. DOI: 10.1016/j.jenvman.2014.04.027.

15. Pidlisnyuk, V., Stefanovska, T., Lewis, E.E., Erickson, L.E. \& Davis, L.C. (2014). Miscanthus as a productive biofuel crop for phytoremediation. Criti. Rev. Plant Sci. 33(1), 1-19. DOI: 10.1080/07352689.2014.847616.

16. Techer, D., Martinez-Chois, C., Laval-Gilly, P., Henry, S., Bennasroune, A., D’Innocenzo, M. \& Falla, J. (2012). Assessment of miscanthus $\mathrm{x}$ giganteus for rhizoremediation of long term pah contaminated soils. Appl. Soil Ecol. 62, 42-49. DOI: 10.1016/j.apsoil.2012.07.009.

17. Kocon, A. \& Matyka, M. (2012). Phytoextractive potential of miscanthus giganteus and sida hermaphrodita growing under moderate pollution of soil with $\mathrm{Zn}$ and $\mathrm{Pb}$. J. Food, Agri. \& Environ. 10(2), 1253-1256.

18. Hodkinson, T., Renvoize, S. \& Chase, M. (1997). Systematics of miscanthus. Aspects Appl. Biol. 49, 189-198.

19. Kahle, P., Beuch, S., Boelcke, B., Leinweber, P. \& Schulten, H.R. (2001). Cropping of miscanthus in central europe: Biomass production and influence on nutrients and soil organic matter. Eur. J. Agron. 15(3), 171-184. DOI: 10.1016/ S1161-0301(01)00102-2.

20. Speller, C.S. (1993). The potential for growing biomass crops for fuel on surplus land in the UK. Outlook Agricu. 22(1), 23-29.

21. Huisman, W., Venturi, P. \& Molenaar, J. (1997). Costs of supply chains of miscanthus giganteus. Industrial Crops and Products. 6(3-4), 353-366. DOI: 10.1016/S0926-6690(97)00026-5.

22. Semere, I.T. \& Slater, F.M. (2007). Invertebrate populations in miscanthus (Miscanthus $\times$ giganteus) and reed canarygrass (Phalaris arundinacea) fields. Biomass and Bioenergy. 31(1), 30-39. DOI: 10.1016/j.biombioe.2006.07.002.

23. Hedde, M., Van Oort, F., Boudon, E., Abonnel, F. \& Lamy, I. (2013a). Responses of soil macroinvertebrate communities to Miscanthus cropping in different trace metal contaminated soils. Biomass and Bioenergy. 55, 122-129. DOI: 10.1016/j.biombioe.2013.01.016.

24. Hedde, M., van Oort, F., Renouf, E., Thénard, J. \& Lamy, I. (2013b) Dynamics of soil fauna after plantation of perennial energy crops on polluted soils. Appl. Soul Ecol. 66, 29-39. DOI: 10.1016/j.apsoil.2013.01.012.

25. Al Souki, K.S., Louvel, B., Douay, F. \& Pourrut, B. (2017). Assessment of Miscanthus x giganteus capacity to restore thefunctionality of metal-contaminated soils: Ex situ experiment. Appl. Soil Ecol. 115(7), 44-52. DOI: 10.1016/j. apsoil.2017.03.002.

26. Clifton-Brown, J., Hastings, A., Mos, M., McCalmont, J.P., Ashman, C., Awty-Carroll, D., Cerazy, J., Chiang, Y.C., Cosentino, S. \& Cracroft-Eley, W., et al. (2017). Progress in upscaling miscanthus biomass production for the european bio-economy with seed-based hybrids. Global Change Biol. Bioen. 9, 6-17. DOI: 10.1111/gcbb.12357.

27. Pidlisnyuk, V., Erickson, L., Kharchenko, S. \& Stefanovska, T. (2014). Sustainable land management: Growing miscanthus in soils contaminated with heavy metals. J. Environ. Protec. 5(8), 723-730. DOI: 10.4236/jep.2014.58073.

28. Pidlisnyuk, V., Trögl, J., Stefanovska, T., Shapoval, P. \& Erickson, L. (2016). Preliminary results on growing second generation biofuel crop miscanthus $\mathrm{x}$ giganteus at the polluted military site in Ukraine. Nova Biotechnol. Chim. 15(1), 77-84. DOI: $10.1515 /$ nbec-2016-0008.

29. Stefanovska, T., Pidlisnyk, V. \& Tomashkin, J. (2015). Growing second generation biofuel plant Miscanthus $\mathrm{x}$ giganteus at military soils contaminated with heavy metals. Bioenergy. 1, 50-53. (in Ukrainian).

30. Andersen, J. (2000, February) Management of contaminated sites and land in Central and Eastern Europe. Retrieved June 2, 2017, from http://www.statensnet.dk/pligtarkiv/fremvis.pl

31. Lindberg, A.L., Goessler, W., Gurzau, E., Koppova, K., Rudnai, P., Kumar, R., Fletcher, T., Leonardi, G., Slotova, K. \& Gheorghiu, E., et al. (2006). Arsenic exposure in Hungary, Romania and Slovakia. J. Environ. Monit. 8(1), 203-208. DOI: 10.1039/B513206A.

32. Leonardi, G., Vahter, M., Clemens, F., Goessler, W., Gurzau, E., Hemminki, K., Hough, R., Koppova, K., Kumar, R. \& Rudnai, P., et al. (2012). Inorganic arsenic and basal cell carcinoma in areas of Hungary, Romania, and Slovakia: A case-control study. Environ. Health Perspect. 120(5), 721-726. DOI: 10.1289/ehp.1103534.

33. Ceřveny, J. (2017). Experience on sanitation of contaminated places at the sites after Soviet Army. At: Materials of the workshop in the field of contaminated sites, Banska Bystrica, Slovakia. Available at: http://old.sazp.sk/public/index/ go.php?id=2229HOME (in Slovakian).

34. State Standard of Ukraine. (2001). Ukrainian standard: Soil quality. Preliminary preparation of samples for physicalchemical analysis. DSTU ISO 11464-2001. Kyiv, Ukraine.

35. State Standard of Ukraine. (2007). National standard of Ukraine. Quality of soil. The method for determination of the nitrate and ammonium nitrogen. DSTU 4729-2007. Kyiv, Ukraine.

36. State Standard of Ukraine. (2004). National Standard of Ukraine. Quality of soil. The method for determination of organic matter. DSTU 4289-2004. Kyiv, Ukraine.

37. Mehlich, A. (1978). New extractant for soil test evaluation of phosphorus, potassium, magnesium, calcium, sodium, manganese and zinc. Commun. Soil Sci. Plant Anal. 9(6), 477-492. DOI: 10.1080/00103627809366824.

38. United States Environmental Protection Agency. (2007). United States Standard: Field Portable X-Ray Fluorescence Spectrometry for the Determination of Elemental Concentrations in Soil and Sediment. SW-846 Test Method 6200-2007. Washington DC.

39. State Standard of Ukraine. (2007). General requirements for the competence of testing and calibration laboratories. DSTU ISO/IEC 17025. Kyiv, Ukraine.

40. Altman, D.G. (1990). Practical statistics for medical research. London: Chapman \& Hall.

41. Hammer, Ø., Harper, D.A.T. \& Ryan, P.D. (2001) PAST: Paleontological statistics software package for education and data analysis. Palaeontol. Electron. 4(1): 9pp. http://palaeoelectronica.org/2001_1/past/issue1_01.htm.

42. Hettiarachchi, G.M., Attanayake, C.P., Defoe, P.P. \& Martin, S.E. (2016). Mechanisms to reduce risk potential. Sowing seeds in the city, Springer. 3, 155-170. DOI: 10.1007/978-94017-7456-7_13.Essington, M.E. (2015). Soil and water chemistry: An integrative approach (2nd ed.). CRC press: Taylot \& Francis Group.

43. Hettiarachchi, G.M., Attanayake, C.P., Defoe, P.P. \& Martin, S.E. (2016). Mechanisms to reduce risk potential. Sowing seeds in the city, Springer. 3, 155-170. DOI: 10.1007/97894-017-7456-7_13. 